\title{
Empirical Study of Influential Factors of Online Customers' Repurchase Intention
}

\author{
Yuping Li \\ School of Business Planning, Chongqing Technology and Business University, Chongqing, China \\ Email:ctbulyp@163.com
}

How to cite this paper: Li, Y.P. (2016) Empirical Study of Influential Factors of Online Customers' Repurchase Intention. iBusiness, 8, 48-60.

http://dx.doi.org/10.4236/ib.2016.83006

Received: August 5, 2016

Accepted: September 9, 2016

Published: September 13, 2016

Copyright (@) 2016 by author and Scientific Research Publishing Inc.

This work is licensed under the Creative

Commons Attribution International

License (CC BY 4.0).

http://creativecommons.org/licenses/by/4.0/

(c) (†) Open Access

\begin{abstract}
There is not a unanimous conclusion about the influential elements of online customers' repurchase intention. We established a concept model and discussed how utilitarian values (perceived ease of use and perceived usefulness), social values (satisfaction and trust) and the hedonic value (perceived enjoyment) directly and indirectly influenced customers' repurchase intention in the context of online shopping. It adapted questionnaire to collect data and testified the hypothesis by structural equation model. The results showed that perceived usefulness, online customers' satisfaction and perceived enjoyment had significantly positive impact on online customers' repurchase intention. Moreover, we found that compared with utilitarian factors, the hedonic factor had a stronger positive impact on repurchase intention.
\end{abstract}

\section{Keywords}

Perceived Ease of Use, Perceived Usefulness, Customer Satisfaction, Customer Trust, Perceived Enjoyment

\section{Introduction}

With the development of the Internet, e-commerce has changed the people how to buy and customers become accustomed to using the Internet instead of the store to make purchase. Compared with the traditional business model, online shopping has a wide range of selectivity and "one-stop" shopping; moreover there aren't the obstacles of time, space and circulation, etc. Klopping and Earl (2004) pointed out that the previous literature focused on the first use of information technology or explored the influencing factors of the first purchasing behavior on online shopping, and these findings could increase customers' usage of information technology and guide the development of online shopping [1]. Along with the increase of the number of the online shopping, the online shopping market had become more and more familiar by customers and turned 
into a relatively mature market. From the perspective of marketing, the cost to retain an old customer is five times of developing a new customer and the main task of e-commerce businesses has been transformed from attracting new customers and improving the growth rate of customers to enhancing the repurchase intention. Lee et al. (2009) suggested that the growth rate of $5 \%$ in customer retention could make the profit increase from $25 \%$ to $75 \%$ [2], so it is necessary to identify the influencing factors of online customers' repurchase intention.

Online shopping customers have dual identities as both buyers and computer users, therefore the influencing factors of online customers' repurchase behavior are complex and different from the traditional purchasing activities. Based on rational action theory and the theory of planned behavior, David (1986) proposed the technology acceptance model [3]. The model indicated that perceived ease of use and perceived usefulness affected the acceptance and use intention of the technology. Lee et al. (2011) also demonstrated that two factors could influence the repurchase intention of online customers [4]; Lee et al. (2009) suggested that satisfaction was one of the important factors affecting repurchase intention of online customers [2]; Pappas et al. (2014) noted that satisfaction had been integrated into the technology acceptance model to interpret repurchase intention of online customers and the level of purchase experience, trust would have a positive effect on satisfaction [5]. An important factor of physical environment is entertaining and it has become increasingly important in online shopping. Al-Maghrabi (2011) verified that the effect of perceived usefulness, perceived enjoyment and social pressure on continuous intention of online customer [6]. The study discusses the direct and indirect impact on online customers' repurchase intention by integrating perceived ease of use, perceived usefulness, online customer trust, online customer satisfaction and perceived enjoyment and though these factors are separately mentioned by the articles, they haven't been used as the whole framework to explain their impact on customers' repurchase intention.

\section{Theoretical Background}

\subsection{The Two Basic Variables of Technology Acceptance Model}

Technology acceptance model can explain and anticipate the willingness of individual acceptance of information technology and it identifies with the causal explanation about the rational action theory on the acceptance of information technology. The model considers perceived ease of use and perceived usefulness are the major influencing factors on the acceptance behavior. Consistent with the rational action theory, the cognitive attitude determines the actual usage behavior and perceived ease of use and perceived usefulness work in attitude, at the same time perceive ease of use influences perceive usefulness, in addition to there are a number of external variables can play roles in perceived usefulness and perceive ease of use of information system.

Perceived usefulness (PU) was defined as the degree which their job performance was improved by using information system (David, 1986) [3]. Under the e-commerce environment, $\mathrm{PU}$ is the degree which customers' success rate is enhanced by using the 
e-commerce websites. In general, PU can advance the purchase efficiency, results and the quality of life. Xu et al. (2013) pointed out that the quality of information, information satisfaction and perceived ease of use affect the perceived usefulness and PU influenced attitude and usage intention of new technologies [7]; Pavlou (2003) thought that PU had a significant impact on purchasing attitude, willing to buy and buying behavior and PU was an important variable in the technology acceptance model to predict the acceptance or usage behavior of customer [8].

Perceived ease of use (PEOU) was defined as the complexity about the use of a specific information system (David, 1986) [3]. After the new generation of information technology, firstly people consider the value and cost by using it. If the IT operation is complicated and takes a lot of time to learn to use it, people will abandon the use of the technology because the costs are greater than the value you get, and only when the costs are less than the value, people will be willing to use it. Childers et al. (2001) suggested that a clear navigation and convenience affected PEOU and in turn affect the customer's purchase attitude [9]; Pavlou (2003) discussed the relationship between PEOU and purchase intention and the results indicated that PEOU had a significant positive effect on purchase intention [8], but Xu et al. (2013) thought that the satisfaction perception of IT acted on PEOU and attitudes had mediating roles between PEOU and usage intention [7]. Different scholars believe that PEOU has many different roles, however in the literatures PEOU can be found to predict the customer behavior in e-commerce environment and $\mathrm{PEOU}$ is a basic variable in technology acceptance model.

\subsection{Online Customer Satisfaction}

Although there are various definitions and classifications of online customer satisfaction, the major ideas are two kinds: the cognitive process was formed when the returns were compared with the costs; the emotional state arising from the customer evaluation process. The study is in accordance with the second classification and the main concern is the emotional state of the customer rather than the cognitive processes, that is, online customer satisfaction refers to the affective state of joy or disappointment after purchasing products or services in the internet. Loiacono et al. (2002) discussed the expected impact of site quality on the repeated use of website, where website quality incorporated five dimensions: ease of use, usefulness, entertainment, complementary relationship and customer service and the result showed website quality had a significant positive effect on the repeated use [10]. Kim et al. (2009) discussed the importance role of the quality of the site, online customer trust and online customer satisfaction in the formation of online customer loyalty, and the results pointed out online customer satisfaction had a significant positive role on online customer loyalty, satisfaction played a mediating role between online customer trust and loyalty which online customer satisfaction was affected by the site's credibility and website design [11].

\subsection{Online Customer Trust}

There are two different categories of online customer trust, the first is that people ob- 
tain a desired target depending on the specific beliefs with trading partner in the risk environment, and the specific belief is goodwill, honest and ability; the second is that people are trustworthy. In the study online customer trust is defined the specific aspects of customers on online vendors about the ability of suppliers, goodwill and honest attitude, which the ability refers to the trustee complete the expected responsibility of the trustee and goodwill represents even if given some kind of opportunity, the trustee don't use the opportunistic behavior and that honesty is the trustee is honest and will comply their commitments. The trust was integrated with technology acceptance mode to discuss the effect of the trust, perceived usefulness and perceived ease of use on the usage intention and the results showed that perceived ease of use had a significant effect on online customer trust, and the trust had a significant effect on perceived usefulness, further the three variables had a significant effect on users' intention (Gefen et al., 2003) [12].

\subsection{Perceived Enjoyment}

Childers et al. (2001) pointed out that perceived usefulness and perceived ease of use are functional motivation factors and perceived enjoyment is an entertainment factor [9]. Emotional and cognitive reactions of customers under the network environment are very important, because they are required in online shopping. Emotional reaction is induced by the process of interaction between people and environments, and perceived enjoyment is proposed in order to conceptualize emotional reactions. Nysveen et al. (2005) suggested that perceived enjoyment is intrinsic rewards form the use of technology and service [13]. Perceived entertainment is a measure of the user's emotion and it refers that whether it is fun in the interaction with the information system. Xu et al. (2013) focused on the customer's emotional state by studying the enjoyment of online shopping and showed that perceived enjoyment is an important affective component [7]. According to self-determination theory, customers can make their own decisions and they will generate internal drive behavior when they are interested in a website or prefer shopping in a website.

\section{Research Model and Hypotheses}

This study aims to investigate the influencing factors of online customer repurchase intention. A conceptual model is constructed and it focuses on the direct and indirect effect of the functional value (perceived usefulness and perceived ease of use), social value (customer trust and satisfaction) and hedonic value (perceived enjoyment) on the customer repurchase intention under network environment. The conceptual model is shown in Figure 1.

Chiu et al. (2009) reported that perceived usefulness is the extent of using the e-commerce websites to improve trading results [14]. Perceived usefulness is an important prerequisite about the acceptance of online shopping and it is produced in the expectation for the sites. If the service provided by the sites can meet customer expectation, the sites are useful, or else it is unnecessary. David et al. (1989) suggested that perceived 


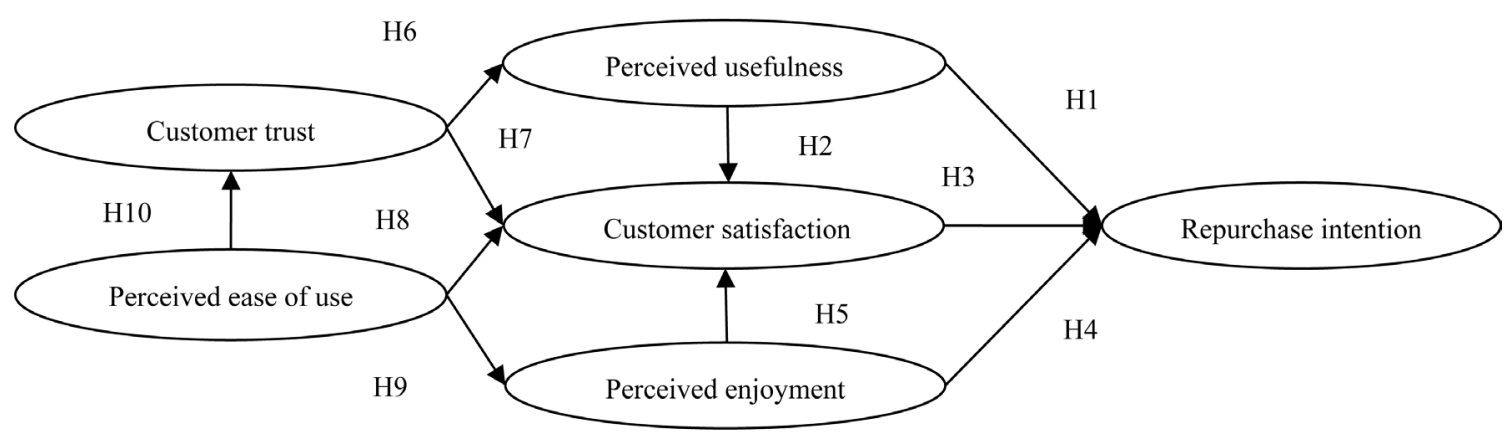

Figure 1. Conceptual model.

usefulness is a key driver factor and it can affect the user's behavior by improving the results of the use of information technology [15]. Perceived usefulness can predict users' usage intention, behavior and the extent of use, and the behavioral intention of people mainly rely on the cognitive behavioral evaluation originated from the results of bargaining with e-commerce websites. When customers achieve success in online shopping, their level of satisfaction will increase. Deng et al. (2010) considered that when technology can provide useful function to customers, the value will enhance customer satisfaction [16]. Based on the study of Bhattacherjee (2001) [17], when customers believe that information technology is useful, they will be satisfied and will likely increase the continuous intention or repurchase intention. So,

Hypothesis 1: Perceived usefulness has a positive effect on customers' repurchase intention in online shopping.

Hypothesis 2: Perceived usefulness has a positive effect on customers' satisfaction in online shopping.

Zeithaml (2000) believed that companies can achieve high customer retention, positive word-of-mouth and additional profit by improving customer satisfaction [18]. Satisfaction is the emotional response which can make customer focus on goals and influence customer behavior. According to expectation confirmation theory, satisfied customers will generate high achievement expectation on future behavior and the possibility of continuance purchase intention will boost. Oliver (1980) declared that satisfaction has a positive effect on future purchase intention and the frequency of patronizing in online shopping is decided by customer satisfaction [19]. Hsu et al. (2006) suggested that satisfaction has a positive effect on customer repurchase intention [20]. Therefore,

Hypothesis 3: Customer satisfaction has a positive effect on customers' repurchase intention in online shopping.

From the perspective of intrinsic motivation, the happiness, joy and fun can inspire people's behavior. Perceived enjoyment is defined that the process of using the information technology is enjoyable removing any possibility of the consequences and it is a form of intrinsic motivation, moreover many researchers believe that intrinsic motivation can be used to interpret the acceptance and usage of information technology in network environments. Perceived enjoyment is considered as intrinsic motivation in 
online shopping. Customers can get a lot of product information and can freely browse and compare the products at various online stores and even can be unobstructed to communicate with service workers, so it is more interesting and challenging for customers to buy suitable products and this intrinsic motivation causes customers to feel that they contact with the online stores. If customers insist that online shopping is pleasant, they are more likely to think that it is beneficial to them and develop a higher degree usage intention. David et al. (1992) considered that when people experience the joy in the process of using computers, individuals will be more frequent use of it and when online shopping is pleasant, there will be a higher continuous willingness to use [21]. Hirschman and Holbrook (1982) indicated that positive consumer experience under entertainment environment-related is likely to produce high level of customer commitment and repurchase intention [22]. Chiu et al. (2009) also considered that entertainment has a positive effect on online customer behavior, for example, increasing customers' reuse intention [14]. Hence,

Hypothesis 4: Perceived enjoyment has a positive effect on customers' repurchase intention in online shopping.

Hypothesis 5: Perceived enjoyment has a positive effect on customers' satisfaction in online shopping.

Trust becomes more important because of the uncertainty of space and objective factors in online shopping and people interact with e-commerce site and online vendors, so the main obstacles that affect the enthusiasm of customers in online shopping are distrusting e-commerce sites and online vendors. It is difficult for customers to estimate whether their choices is trustworthy because they cannot check the online stores, firsthand experience the products and guarantee the security of payment. Trust is a belief that the individuals believe that others are goodwill, competent and honesty. If e-commerce websites cannot meet the belief of trust, customers will not expect to get any functional value and interests. Gefen et al. (2003) pointed out that online customer trust plays a significant role in deciding the willingness to accept the e-commerce, and when e-commerce websites is trustful and is beneficial to customers, they will finally agree with the usefulness of websites [12]. Online customer trust is an important driving factor of perceived usefulness.

When customers only search information online, the trust is not so important, but when the transactions occur, customer trust is very necessary. Customers must feel safe in the process of online shopping and it is responsibility for e-commerce websites to improve and retain trust. Chiu et al. (2009) suggested that the higher the trust, the higher the satisfaction and trust maybe a prerequisite of satisfaction, because when service failure happens, trust and satisfaction is an important factor of customer retention [14]. Therefore,

Hypothesis 6: Online customer trust has a positive effect on perceived usefulness in online shopping.

Hypothesis 7: Online customer trust has a positive effect on customers' satisfaction in online shopping.

Perceived ease of use reflects the simplicity and clarity of e-commerce sites and when 
customers search information and purchase products online, the extent of customers' effort affect their acceptance of online shopping. Shen and Chiou (2010) indicated that some e-commerce sites use higher validation requirements in order to improve the security of online shopping and customers need to experience many steps to purchase products which will affect the satisfaction of customers [23]. Kim and Gupta (2009) considered that when the technology of e-commerce is complex and is difficult to learn, perceived enjoyment will decline and if the websites can be easily and quickly to learn to use, perceived enjoyment will increase [24]. According to the theory of self-effectiveness, perceived ease of use affects intrinsic motivation and if customers have high self-competence (i.e., perceived ease of use), they are more likely to produce the sense of pleasure in the process of using information technology. Lohse and Spiller (1998) showed that perceived ease of use affects online customer trust and some features of e-commerce sites, such as easy search, interactive and navigation are associated with trust [25]. So,

Hypothesis 8: Perceived ease of use has a positive effect on customers' satisfaction in online shopping.

Hypothesis 9: Perceived ease of use has a positive effect on perceived enjoyment in online shopping.

Hypothesis 10: Perceived ease of use has a positive effect on customers' trust in online shopping.

The perspective of functional motivation and hedonic motivation had been applied to the research of online customers' purchasing behavior, however the relative importance of the function and enjoyment factor didn't gain consistent conclusion and the conflict still exists in the research of e-commerce. Shang et al. (2005) indicated that compared with functional factors (perceived usefulness), hedonic factors (such as fashion and cognitive experience) are more important in the interpretation of online customer purchasing behavior [26]. To et al. (2007) showed that functional motivation can explain online customer behavior [27], but few studies discussed the effect of functional factors and hedonic factors on the future behavior of online customers. In the case of a conflict about the relative importance of functional factors and hedonic factors, the study suggests that compared with functional motivation, hedonic motivation has a stronger effect on online customer repurchase intention. The higher the hedonic factors, the higher the emotional value and when customers experience positive emotions in a fun environment, they will form a strong relationship commitment, further emotional ties play an important commitments in relationship commitment. This connection between emotional and commitment will cause emotional reaction and will be easy to influence customer repurchase behavior. Therefore,

Hypothesis 11: Compared with perceived usefulness, perceived enjoyment has a stronger effect on customer repurchase intention in online shopping.

\section{Research Methodology}

\subsection{Measurement}

The measuring scale of variables is gained by reading foreign literature and the study 
invite 20 graduate students who have a rich experience of online shopping to evaluate the consistency, the complexity and the order of the questionnaire, etc, then the quality of questionnaire was determined by in-depth interviews of small-scale.

The measurements for online customer trust were adapted from Gefen et al.'s (2003) and Lee et al.'s (2011) study [4] [12]. The measurements for perceived ease of use and perceived usefulness were adapted from Chiu et al.'s (2009) and Lee et al.'s (2011) study [4] [14]. The items for online customer satisfaction were adapted from Hsu et al.'s (2006) study [20]. The items for perceived enjoyment and online repurchase intention were adapted from Al-Maghrabi et al.'s (2011) study [6]. The questionnaire includes three parts: the basic introduction, body and the survey, firstly we asked the survey whether they had an experience in online in past six months because it is difficult to reflect the customer's real thoughts in a long time. The variables were measured by seven Likert scale, such as 1 strongly disagree, 7 strongly agree.

\subsection{Participants}

The research discuss customers' views on the websites which they always browse or shop and most of the respondents are college students who have online shopping experiences in the past six months. A majority of online customers are young and have high educational background, so university students are representative and to some extent they are the main population of online shopping in the future. This study used a convenience sample and the questionnaires were mainly issued in the libraries and classrooms of two universities. A total of 250 questionnaires were formed and some questionnaires were excluded because the samples haven't had the online shopping in the past six months, the answers were incomplete and other random answer et al.. Finally, a total of 210 valid questionnaires were received. The demographic characteristics of samples were shown in Table 1.

\section{Data Analysis and Results}

\subsection{Reliability and Validity Analysis}

Table 2 shows Cronbach's alphas, AVE (average variance extracted) and composite reliability of the different latent variables. According to the value of Cronbach's alphas, we can estimate the reliability of model and the Cronbach's alphas of six latent variable were higher than 0.7 , so the model has a good internal consistency. Then the convergent validity will be assessed and the composite reliability of each latent variable is between $0.828 \sim 0.879$ (more than the level of 0.7 ) which was calculated based on factor loading of the model, and the AVE (average variance extracted) are more than 0.546 (higher than the critical value of 0.5 ) indicating that the model has good convergent validity.

Further, we test the discriminant validity of each potential variables using AVE. As indicated in Table 3, the AVE value (the value of diagonal) of six latent variables were greater than the square of the correlation coefficient between it and other variables, which shows a good discriminant validity between each latent variable. 
Table 1. Demographics $(\mathrm{N}=210)$.

\begin{tabular}{|c|c|c|c|c|c|}
\hline \multicolumn{2}{|l|}{ Classification } & \multirow{2}{*}{$\begin{array}{c}\text { Frequency } \\
54.3 \%\end{array}$} & \multicolumn{2}{|c|}{ Classification } & \multirow{2}{*}{$\frac{\text { Frequency }}{45.7 \%}$} \\
\hline Gender & Male & & Gender & Female & \\
\hline \multirow{4}{*}{ Age group } & $<18$ & $5.2 \%$ & \multirow{4}{*}{ Education } & Junior high school and below & $0 \%$ \\
\hline & $18-25$ & $77.6 \%$ & & High school/technical Secondary school & $7.6 \%$ \\
\hline & $26-30$ & $12.9 \%$ & & college & $47.6 \%$ \\
\hline & $>31$ & $4.3 \%$ & & Graduate school & $44.8 \%$ \\
\hline \multirow{5}{*}{$\begin{array}{l}\text { The time of using internet (in } \\
\text { years) }\end{array}$} & $<1$ year & $1.4 \%$ & \multirow{5}{*}{$\begin{array}{l}\text { The time of online shopping (in } \\
\text { years) }\end{array}$} & $<1$ year & $10 \%$ \\
\hline & 1 to 3 years & $11.9 \%$ & & 1 to 3 years & $20.9 \%$ \\
\hline & 4 to 6 years & $28.6 \%$ & & 4 to 6 years & $35.7 \%$ \\
\hline & 7 to 9 years & $32.9 \%$ & & 7 to 9 years & $4.8 \%$ \\
\hline & $>10$ years & $25.2 \%$ & & $>10$ years & $28.6 \%$ \\
\hline
\end{tabular}

Table 2. Cronbach' $\alpha$, AVE and composite reliability.

\begin{tabular}{crcc}
\hline Construct & Cronbach' $\alpha$ & AVE & Composite reliability \\
\hline TR & 0.870 & 0.594 & 0.879 \\
PEOU & 0.829 & 0.546 & 0.828 \\
PU & 0.833 & 0.561 & 0.836 \\
SAT & 0.877 & 0.700 & 0.875 \\
PE & 0.850 & 0.587 & 0.849 \\
RP & 0.888 & 0.591 & 0.878 \\
\hline
\end{tabular}

Table 3. AVE and the square of the correlation coefficient.

\begin{tabular}{ccccccc}
\hline & TR & PEOU & PU & PE & SAT & RP \\
\hline TR & 0.594 & & & & \\
PEOU & 0.153 & 0.546 & & & \\
PU & 0.164 & 0.476 & 0.561 & & & \\
PE & 0.356 & 0471 & 0.276 & 0.587 & & \\
SAT & 0.443 & 0.243 & 0.293 & 0.447 & 0.700 & \\
RP & 0.306 & 0.311 & 0.324 & 0.515 & 0.544 & 0.591 \\
\hline
\end{tabular}

\subsection{Model Test}

The goodness of fit test was carried out using AMOS 18.0 and the model fitting has several standards: the ratio of $\chi^{2}$ and the degrees of freedom less than 2; the value of RMSEA (root-mean-square error of approximation) between 0.05 to 0.08 represents a good model; the values of IFI (Incremental Fit Index), TLI (Tucker-Lewis Index) and CFI (Comparative Fit Index) are all between 0 and 1, and that the closer to 1 indicates the better fit of model. The fit indices of model as follows: $\chi^{2} / \mathrm{df}=1.828$, RMSEA $=$ 
$0.06, \mathrm{IFI}=0.931, \mathrm{TLI}=0.919, \mathrm{CFI}=0.930$ and the indicators are better fitting. The results show the model matches the data.

Table 4 shows the specific parameters of latent variables, the results show that all other hypothesizes have been verified in addition to the hypothesis 8 (Figure 2).

\section{Discussion}

\subsection{Theoretical Contributions}

The online customers' repurchase intention is the current hot research issue because most Internet users have online shopping experiences and retailers begin to focus on the post choice behavior. The results show that the e-commerce websites should emphatically consider the hedonic value of customers, whether they can offer interest and joy in online shopping is the most important factor, however, functional factors are also important to online customers because perceived usefulness also has a significant positive effect on online customers' repurchase intention. So when improving the hedonic value of the site is a priority, online vendors also need to consider how to meet the functional value of the customer.

Table 4. Regression coefficient.

\begin{tabular}{cccccc}
\hline Hypothesis & Path & Standardized Coefficient & T Value & P Value & Accepted/Rejected \\
\hline H1 & PU $\geq$ RP & 0.156 & 2.136 & 0.033 & Accepted \\
H2 & PU $\geq$ SAT & 0.251 & 2.672 & 0.008 & Accepted \\
H3 & SA $\geq$ RP & 0.412 & 4.596 & $* * *$ & Accepted \\
H4 & PE $\geq$ RP & 0.360 & 3.983 & $* * *$ & Accepted \\
H5 & PE $\geq$ SAT & 0.367 & 3.307 & $* * *$ & Accepted \\
H6 & TR $\geq$ PU & 0.159 & 2.245 & 0.025 & Accepted \\
H7 & TR $\geq$ SAT & 0.377 & 4.690 & $* * *$ & Accepted \\
H8 & PEOU $\geq$ SAT & -0.08 & -0.687 & 0.492 & Rejected \\
H9 & PEOU $\geq$ PE & 0.686 & 7.421 & $* * *$ & Accepted \\
H10 & PEOU $\geq$ TR & 0.391 & 4.846 & $* * *$ & Accepted \\
H11 & PU $\geq$ RP $>$ PE $\geq$ RP & & & & Accepted \\
\hline
\end{tabular}

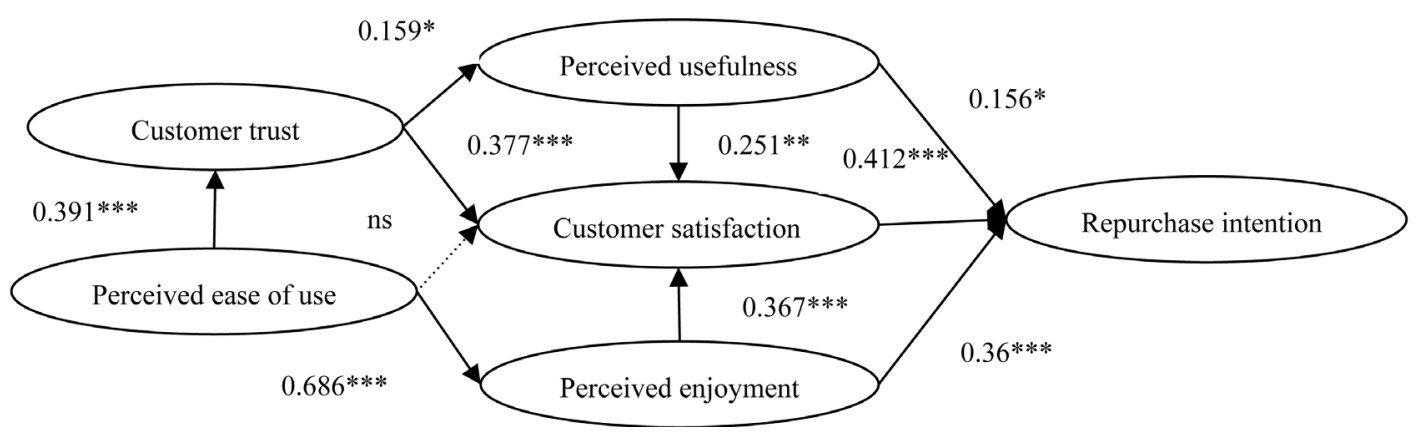

Figure 2. Final path model. 
The study constructed an integrated framework model of online customers' repurchase intention and tested the direct and indirect effect on customer trust, perceived ease of use, perceived usefulness, online customer satisfaction, and perceived enjoyment on online customers' repurchase intention. Because respondents are both online shopping customers and users of the site, this research provides a more comprehensive idea to us, that is, we discuss the effect of the factors relating to the field of information system, marketing and social psychology on online repurchase intention. The study also points out that the technology acceptance model can predict not only user behavior to acceptance of information technology but also continuous use intention and the conclusion is that online customer satisfaction hasn't the mediating effect between perceived ease of use and customers' repurchase intention, because with the increasing of online purchase and the familiar with the shopping sites, customer perception of ease of use would be high, but the price, quality and service etc. probably would not have been growing, hence the relationship between perceived ease of use and online customer satisfaction is not obvious.

\subsection{Practical Contributions}

E-commerce enterprises should focus on improving perceived enjoyment of websites. Firstly online shopping websites ought to timely introduce some fashion merchandise. In browsing the sites many customers don't have a certain purpose and they are just looking whether there are any new styles. When customers find commodities they prefer, they are likely to have impulse buying behaviors, so in a timely manner to launch trendy merchandise can increase the desire to buy more and stimulate consumption; secondly the e-commerce websites should do some promotional activities: 1) in a period of time different discount is implemented for different commodities and consumers need to purchase at specific times, for example, Taobao's bargain activity is a limited-time discount of successful cases and customers purchase goods at a discount within 24 hours. 2) Tmall double 11 is the full reduction by using coupons. Before double 11 arrival, customers can receive different coupons by browsing the website and coupons can stimulate consumption and increase the numbers of purchasing or collocation purchase. Finally, e-commerce sites can increase the interaction between the customers, such as in the form of online chat rooms and online forums. In a word, e-commerce companies can use these methods to increase the hedonic value of online shopping.

E-commerce enterprises should focus on improving perceived usefulness of websites. E-commerce companies should consider the interface design of online shopping which tries to make customers comfortable and the interface design contains graphic design, structural design and content design. In graphic design, the websites should be customer-oriented and the graphics is easily clicked and processed, even the websites should avoid using fancy patterns and colors in selecting the image; in structural design, the classification of goods should be scientificly divided and the layout of sites should not only meet the customer's buying habits, but also be easy and clear to under- 
stand, moreover the navigate and the link ought to reflect the consistency because it helps customers to purchase the good quickly and effectively; in content design, the description of goods tries to be clear and concise and distinguish the priorities, future the websites can use a different font in the important and attractive products and do a detailed presentation for attracting customers attention.

\section{References}

[1] Klopping, I.M. and McKinney, E. (2004) Extending the Technology Acceptance Model and the Task-Technology Fit Model to Consumer E-Commerce. Information Technology Learning and Performance Journal, 22, 35-48.

[2] Lee, H., Choi, S.Y. and Kang, Y.S. (2009) Formation of E-Satisfaction and Repurchase Intention: Moderating Roles of Computer Self-Efficacy and Computer Anxiety. Expert Systems with Applications, 36, 7848-7859. http://dx.doi.org/10.1016/j.eswa.2008.11.005

[3] David, F.D. (1986) A Technology Acceptance Model for Empirically Testing New End-User Information Systems: Theory and results. Massachusetts Institute of Technology, Cambridge.

[4] Lee, C.H., Eze, U.C. and Ndubisi, N.O. (2011) Analyzing Key Determinants of Online Repurchase Intentions. Asia Pacific Journal of Marketing and Logistics, 23, 200-221. http://dx.doi.org/10.1108/13555851111120498

[5] Pappas, I.O., Pateli, A.G., Giannakos, M.N. and Chrissikopoulos, V. (2014) Moderating Effects of Online Shopping Experience on Customer Satisfaction and Repurchase Intentions. International Journal of Retail \& Distribution Management, 42, 187-204. http://dx.doi.org/10.1108/IJRDM-03-2012-0034

[6] Al-Maghrabi, T., Dennis, C., Vaux Halliday, S., et al. (2011) Determinants of Customer Continuance Intention of Online Shopping. International Journal of Business Science and Applied Management, 6, 41-65.

[7] Xu, J.D., Benbasat, I. and Cenfetelli, R.T. (2013) Integrating Service Quality with System And information Quality: An Empirical Test in the E-Service Context. Management Information Systems Quarterly, 37, 777-794.

[8] Pavlou, P.A. (2003) Consumer Acceptance of Electronic Commerce: Integrating Trust and Risk with the Technology Acceptance Model. International Journal of Electronic Commerce, 7, 101-134.

[9] Childers, T.L., Carr, C.L., Peck, J. and Carson, S. (2001) Hedonic and Utilitarian Motivations for Online Retail Shopping Behavior. Journal of Retailing, 77, 511-535. http://dx.doi.org/10.1016/S0022-4359(01)00056-2

[10] Loiacono, E.T., Watson, R.T. and Goodhue, D.L. (2002) WebQual: A Measure of Website Quality. Marketing Theory and Applications, 13, 432-438.

[11] Kim, J. and Forsythe, S. (2008) Adoption of Virtual Try-On Technology for Online Apparel Shopping. Journal of Interactive Marketing, 22, 45-59. http://dx.doi.org/10.1002/dir.20113

[12] Gefen, D., Karahanna, E. and Straub, D.W. (2003) Trust and TAM in Online Shopping: An Integrated Model. MIS quarterly, 27, 51-90.

[13] Nysveen, H., Pedersen, P.E. and Thorbjørnsen, H. (2005) Explaining Intention to Use Mobile Chat Services: Moderating Effects of Gender. Journal of Consumer Marketing, 22, 247 256. http://dx.doi.org/10.1108/07363760510611671

[14] Chiu, C.-M., Chang, C.-C., Cheng, H.-L. and Fang, Y.-H. (2009) Determinants of Customer Repurchase Intention in Online Shopping. Online Information Review, 33,761-784. 
http://dx.doi.org/10.1108/14684520910985710

[15] David, F.D., Bagozzi, R.P. and Warshaw, P.R. (1989) User Acceptance of Computer Technology: A Comparison of Two Theoretical Models. Management Science, 35, 982-1003. http://dx.doi.org/10.1287/mnsc.35.8.982

[16] Deng, L., Turner, D.E., Gehling, R. and Prince, B. (2010) User Experience, Satisfaction, and Continual Usage Intention of IT. European Journal of Information Systems, 19, 60-75. http://dx.doi.org/10.1057/ejis.2009.50

[17] Bhattacherjee, A. (2001) Understanding Information Systems Continuance: An Expectation-Confirmation Model. MIS Quarterly, 25, 351-370. http://dx.doi.org/10.2307/3250921

[18] Zeithaml, V.A. (2000) Service Quality, Profitability, and the Economic Worth of Customers: What We Know and What We Need to Learn. Journal of the Academy of Marketing Science, 28, 67-85. http://dx.doi.org/10.1177/0092070300281007

[19] Oliver, R.L. (1980) A Cognitive Model of the Antecedents and Consequences of Satisfaction Decisions. Journal of Marketing Research, 17, 460-469. http://dx.doi.org/10.2307/3150499

[20] Hsu, M.H., Yen, C.H., Chiu, C.M. and Chang, C.-M. (2006) A Longitudinal Investigation of Continued Online Shopping Behavior: An Extension of the Theory of Planned Behavior. International Journal of Human-Computer Studies, 64, 889-904. http://dx.doi.org/10.1016/j.ijhcs.2006.04.004

[21] David, F.D., Bagozzi, R.P. and Warshaw, P.R. (1992) Extrinsic and Intrinsic Motivation to Use Computers in the Workplace. Journal of Applied Social Psychology, 22, 1111-1132. http://dx.doi.org/10.1111/j.1559-1816.1992.tb00945.x

[22] Hirschman, E.C. and Holbrook, M.B. (1982) Hedonic Consumption: Emerging Concepts, Methods and Propositions. The Journal of Marketing, 46, 92-101. http://dx.doi.org/10.2307/1251707

[23] Shen, C.C. and Chiou, J.S. (2010) The Impact of Perceived Ease of Use on Internet Service Adoption: The Moderating Effects of Temporal Distance and Perceived Risk. Computers in Human Behavior, 26, 42-50. http://dx.doi.org/10.1016/j.chb.2009.07.003

[24] Kim, H.W. and Gupta, S. (2009) A Comparison of Purchase Decision Calculus between Potential and Repeat Customers of an Online Store. Decision Support Systems, 47, 477-487. http://dx.doi.org/10.1016/j.dss.2009.04.014

[25] Lohse, G.L. and Spiller, P. (1998) Electronic Shopping. Communications of the ACM, 41, 81-87. http://dx.doi.org/10.1145/278476.278491

[26] Shang, R.A., Chen, Y.C. and Shen, L. (2005) Extrinsic versus Intrinsic Motivations for Consumers to Shop On-Line. Information \& Management, 42, 401-413. http://dx.doi.org/10.1016/j.im.2004.01.009

[27] To, P.L., Liao, C. and Lin, T.H. (2007) Shopping Motivations on Internet: A Study Based on Utilitarian and Hedonic Value. Technovation, 27, 774-787.

http://dx.doi.org/10.1016/j.technovation.2007.01.001 
Submit or recommend next manuscript to SCIRP and we will provide best service for you:

Accepting pre-submission inquiries through Email, Facebook, LinkedIn, Twitter, etc. A wide selection of journals (inclusive of 9 subjects, more than 200 journals)

Providing 24-hour high-quality service

User-friendly online submission system

Fair and swift peer-review system

Efficient typesetting and proofreading procedure

Display of the result of downloads and visits, as well as the number of cited articles

Maximum dissemination of your research work

Submit your manuscript at: http://papersubmission.scirp.org/ 